\title{
Efficacy of plant resistance inducers on cereal crops against a complex of pathogens
}

\author{
Irina Matveeva*, Anastasia Danilova, Yuriy Kim, Olesya Miroshnichenko, and Alexander \\ Grigoriev
}

All-Russian Research Institute of Biological Plant Protection, Krasnodar-39, 350039, Russia

\begin{abstract}
The article describes the benefits of using plant resistance inducers on cereal crops and the basic principles of their impact on pests development (Pyrenophora tritici-repentis, Puccinia triticina, Puccinia striiformis, Puccinia graminis, Puccinia hordei). The assessment results of the biological and economic effectiveness of L-479 and DL-59 preparations are presented in comparison with the chemical Kolosal,CE and biological Albit, which were used as standards for reducing the development of yellow leaf spot and rust diseases. L-479 product was found to be the most effective on wheat against brown, yellow and stem rust, and yellow leaf spot. Its biological efficacy ranged from $48.3 \%$ to $57.0 \%$ depending on the pathogen, and the increase in grain yield ranged from $3.7 \%$ to $22.1 \%$. DL-59 product showed the best biological efficacy against dwarf leaf rust of barley $-89.8 \%$, the increase in grain yield was $3.5 \%$.
\end{abstract}

\section{Introduction}

Cereal crops are the most widespread around the world and are of great food value. Among the factors significantly reducing their yield, the influence of phytopathogens causing various diseases is of great importance. A high density of sown areas occupied by spike crops and favorable weather conditions of the growing season predispose to frequent outbreaks of diseases. Global warming contributes to the expansion of habitat and increase the harmfulness of crop diseases.

In the south of Russia, yellow leaf spot (Pyrenophora tritici-repentis Died.) is one of the most harmful diseases in the pathogenic complex of winter wheat [1]. The first information on the detection of the pathogen in the North Caucasus appeared in 1985. Since then, this disease has been noted annually. In the areas with sufficient moisture, the development of the disease in production and breeding crops reaches $40-80 \%$, and the incidence reaches $100 \%$. The rust diseases pathogens (brown, yellow, stem, dwarf rust) are the most dangerous and economically significant for cereal crops, seriously threatening the food security of the region and the country as a whole [2]. Wheat brown rust (pathogen -

${ }^{*}$ Corresponding author: irina.matveeva14@yandex.ru 
Puccinia triticina f. sp. tritici Erikss. et Henn.) is the most common wheat disease in Russia and across the world. In susceptible varieties, yield shortages reach $40 \%$ [2]. Wheat yellow (striped) rust (pathogen - Puccinia striiformis West.) is a dangerous, widespread disease over all continents (except Antarctica) in regions with high humidity and low temperatures. Infection during the autumn period, overwintering during soft winters and intensive development during the growing season lead to 70-100\% plant damage and yield shortages amount up to $40-60 \%$ [2]. A high degree of plants damage caused by this disease leads to the formation of shrivelled grain of low quality, to a significant reduction in the germination energy and in the seedling vigor. In southern Russia, an annual increase and expansion of the area of the phytopathogen is noted. Stem rust (biotrophic fungus Puccinia graminis Pers. f. sp. tritici Erik. et Henn.) is the most harmful of all types of rust. With the development of the disease in the years of epiphytoties, yield losses can reach more than $80 \%$ [2]. A special threat is the race UG99, the expansion of its habitat is particularly dangerous for the entire planet. A distinctive feature of rusts is their high adaptive ability. New aggressive races can show high resistance to many chemicals and quickly overcome the resistance of new varieties of crops. Dwarf rust (pathogen - Puccinia hordei Otth.) is a dangerous barley disease, which is highly specialized and belongs to a strictly defined crop. The disease is capable of affecting almost all the aerial parts of barley plants: leaf, leaf sheath, stem, paleas and setae. They are covered with rusty-brown urediniopustules, covered by the epidermis or emerging through tears in damaged tissues. During the periods with optimal weather conditions, the development of dwarf rust in susceptible varieties can reach $60-80 \%$, which, in turn, leads to a significant decrease in the quality and grain yield (up to $30 \%$ ) [2].

Nowadays, eco-friendly protective measures against economically significant phytopathogens are especially important. Environmental safety of the measures recommended for disease control can be achieved through the use of modern promising means of suppressing harmful organisms, such as plant resistance inducers that increase plant resistance to diseases and stress factors [3].

It is known that during evolution process plants developed mechanisms for responding to various types of stress: abiotic - drought, soil salinity, high air temperature [3] and biotic - the influence of harmful microorganisms [4]. These protective mechanisms are inactive and hidden until there is an adverse factor and / or contact with the pathogen [4].

Plants have several protective mechanisms against pathogens. The octadecanoid pathway is one of the most famous mechanisms in plant protection, the end product of which is jasmonic acid - phytohormone, which affects the expression of some genes responsible for the protective response to the stress factor [2]. In addition, this mechanism induces the production of hydrogen peroxide (H2O2) and reactive oxygen (ROS), which can act as the first protective signaling molecule in the plant. A number of other reactive forms, as well as several antioxidant enzymes, are constantly modulated by the plant under the influence of stress factors to overcome them [5-8].

The infection caused by the pathogen leads to changes in the activity of plant cells around the site of invasion and can lead to the induction of resistance, a hypersensitive response characterized by rapid cell death at the site of infection $[9,10]$.

Advances in scientific research on induced systemic resistance (ISR) in plants have been accompanied by the emergence of new commercial products with higher efficacy, stability and less negative environmental impact than current pesticides. According to a number of authors, these products are able to increase agricultural productivity not only by reducing losses caused by pathogenic microorganisms, but also by increasing vegetative growth [11].

Acibenzolar-S-methyl (ASM) was the first commercial inducer, after its synthesis other products followed that are available on the market today. The research to find and develop 
new activator substances (elicitors) is still going on [12]. Secondary compounds of medicinal plants that have direct antimicrobial properties or induce protective reactions inside the plant are also used as plant resistance inducers [13].

The exogenous use of plant resistance inducers (PRI) that can activate protective reactions is one of the integrated method approaches to control harmful organisms. However, the introduction of these substances into agricultural practice requires methods of accelerated but high-quality screening of effective molecules and optimization of their use [14]. The topic of induced plant resistance has been carefully studied with the aim of developing new alternative methods of controlling diseases and minimizing the negative impact on the environment and human health.

An elicitor or inducer is one or more molecules in an organism or formed by the plant itself, whose function is to activate protective responses against a stress factor or pathogen [4]. The metabolites of fungi, bacteria, and viruses can also be resistance inducers, since they consist mainly of proteins and carbohydrates, contained by the cells of the host plant $[13,16]$.

The ASM inductor is a structural and functional analogue of salicylic acid and causes a protective reaction in various plant species against a wide range of pathogenic viruses, bacteria, fungi and nematodes. Studies using this elicitor demonstrate the rapid expression of substances such as glucanases and chitinases [16].

Despite the mentioned positive qualities of plant resistance inducers, they cannot provide absolute efficacy in the diseases control, but, as an element of the integrated plant protection technology, they can improve the quality of the crop and significantly reduce yield losses.

To develop a technology for the use of biorational plant protection products for winter cereal crops against a complex of pathogens of epiphytotic dangerous diseases, we carried out the studies to assess the biological and economic efficacy of L-479 and DL-59 disease resistance inducers on wheat and barley, developed in the laboratory of plant growth regulators at the All-Russian Research Institute of Biological plant protection.

\section{Materials and methods}

The research was carried out in 2018-2019 in the field, upon the artificial infectious background of the pathogens of brown, yellow, stem rust (GROM variety), wheat yellow leaf spot (TANYA variety) and dwarf rust of barley (MIKHAILO variety) at the FSBSI ARRIBPP (Krasnodar). The weather conditions of vegetation seasons were favorable both for the development of plants and the phytopathogenic fungi.

Infestation with wheat yellow leaf spot in the field was carried out using the prepared water-conidial suspension (titer $5 \times 10^{3}$ conidia $/ \mathrm{ml}$ ). A mixture of talc and urediniospore spores in a ratio of 1: 100 with a concentration of $10 \mathrm{mg}$ spores $/ \mathrm{m}^{2}$ for brown, yellow, and dwarf rusts, a concentration of $5 \mathrm{mg}$ spores $/ \mathrm{m}^{2}$ for stem rust were used to inoculate the experimental plots with rusts. The initial registration of the diseases was carried out when the first signs of the infection appeared, the following recordings were carried out until the phase of milk-wax ripeness of grain after 7-10 days (at least three times). Assessment of the degree of the plants damage by rust was calculated as a percentage on the Cobb scale; for wheat yellow leaf spot (P. tritici-repentis), it was calculated according to the Saari and Prescott scales [1, 17].

To assess the efficacy of disease resistance inducers against pathogens, we selected the following preparations: L-479 (chemical class - substituted 2-alkylthionicotinonitriles, $30 \mathrm{~g} / \mathrm{ha}$ ) and DL-59 (substituted thienopyridines, $30 \mathrm{~g} / \mathrm{ha}$ ), developed at the Laboratory of Plant Growth Regulators, FSBSI ARRIBPP. We used Albit, RSS (poly-betahydroxybutyric acid, $0.04 \mathrm{l} / \mathrm{ha}$ ) as the biological standard and Kolosal, CE (tebuconazole, $0.5 \mathrm{l} / \mathrm{ha}$ ) as the 
chemical standard. The treatment was performed twice: the first - according to the first signs of the disease, the second - 10-14 days after the first treatment - phase Z 51. There were three replications of the experiment, the experimental plot area was $6 \mathrm{~m}^{2}$. The initial registration was carried out at the first signs of the disease, then we kept recordings with an interval of 7-10 days. Biological efficacy was calculated by the Abbott's formula:

$$
(100(X-Y) / x=\%
$$

where $\mathrm{X}$ - degree of plant damage in the control option;

$\mathrm{Y}$ - degree of plant damage in the experimental option.

For the research we used the material and technical base of the unique scientific installation "Phytotron for the isolation, identification, study and maintenance of races, strains, phenotypes of pathogens" (http://ckp-rf.ru/671925) and the objects of the Bioresource collection of the FSBSI ARRIBPP "The State Collection of Entomoacariphages and Microorganisms"

\section{Results and discussion}

As a result of the studies, it was found that the double application of the inducers allowed to reduce the development of the pathogens, on average, by 2-4 times. The biological efficacy under the treatment with DL-59 was $58.0 \%$ - against brown rust (the disease development in the control (without treatment) - $10.0 \%$ ), $40.5 \%$ - against yellow rust (the disease development in the control (without treatment) - $12.1 \%$ ), $34.4 \%$ - against stem rust (the disease development in the control (without treatment) - $30.5 \%$ ) (Figure 1).

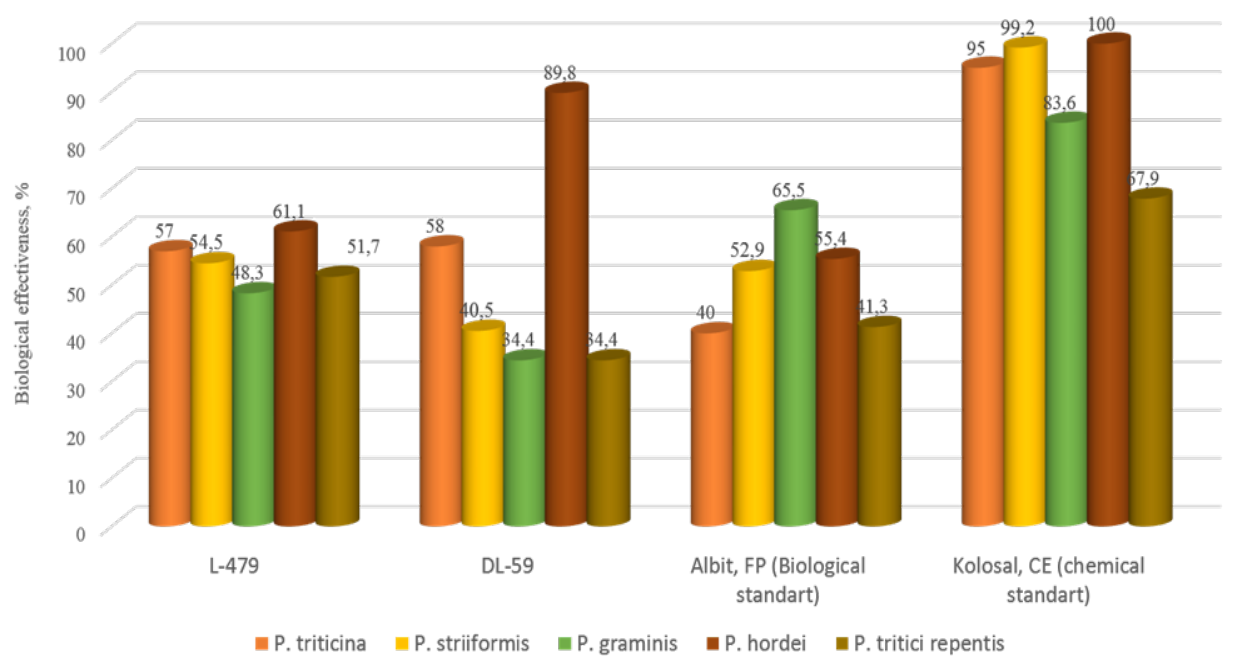

Fig. 1. Biological efficacy of plant resistance inducers DL-59 and L-479 against wheat and barley diseases pathogens, FSBSI ARRIBPP, 2018-2019

The biological efficacy of L-479 application was $57.0 \%, 54.5 \%$ and $48.3 \%$, respectively. When treated with DL-59, the biological efficacy against dwarf rust of barley amounted up to $89.8 \%$, with L-479 - $61.1 \%$; with the development of the disease in the control (without treatment) $-43.6 \%$. The biological efficacy of L-479 and DL-59 against wheat yellow leaf spot was $52.7 \%$ and $34.4 \%$, respectively; with the development of the disease in the control (without treatment) $-29.0 \%$. 
Assessment of economic efficiency showed that the preparation DL-59 provided an increase in grain yield with double treatment against brown rust of $26.2 \mathrm{~g} / \mathrm{m}^{2}(3.8 \%)$; against yellow rust $-55.4 \mathrm{~g} / \mathrm{m}^{2}(7.0 \%)$, against stem rust $-44.5 \mathrm{~g} / \mathrm{m}^{2}(5.7 \%)$, against yellow leaf spot $-96.0 \mathrm{~g} / \mathrm{m}^{2}(12.5 \%)$, against dwarf rust $-24.0 \mathrm{~g} / \mathrm{m}^{2}(3.5 \%)$ (Figure 2$)$.

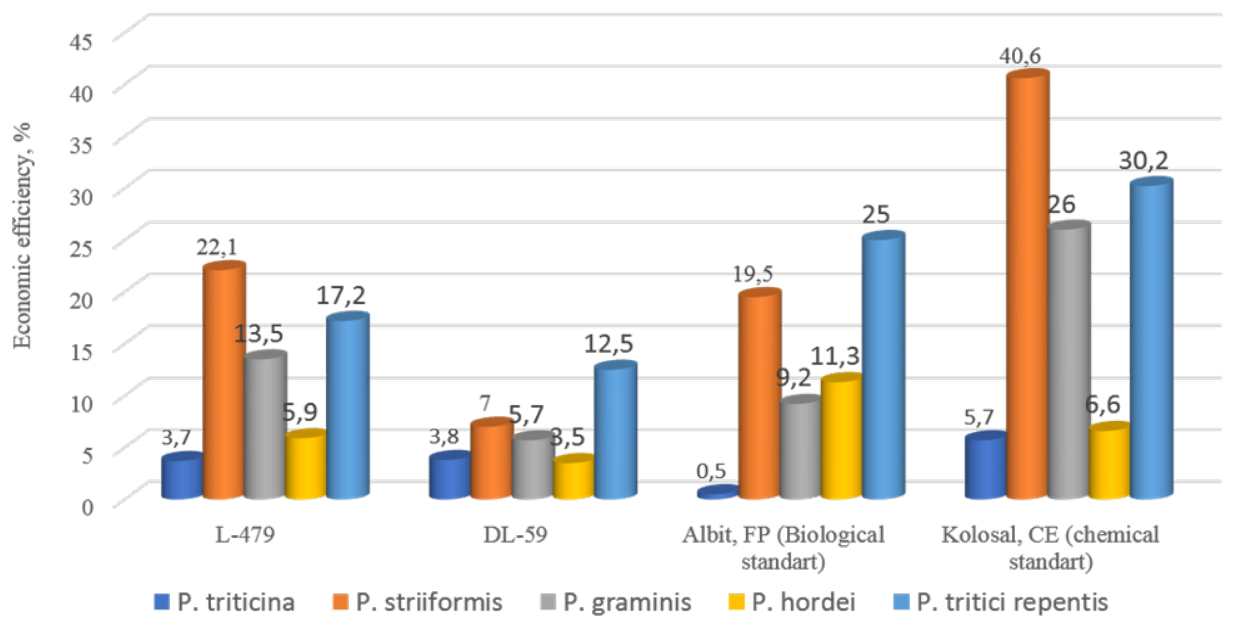

Fig. 2. Economic efficiency of plant resistance inducers DL-59 and L-479 against wheat and barley diseases pathogens, FSBSI ARRIBPP, 2018-2019

The increase in grain yield when double treated with L-479 against brown rust was $25.4 \mathrm{~g} / \mathrm{m}^{2}$ (3.7\%); against yellow rust $-175.4 \mathrm{~g} / \mathrm{m}^{2}(22.1 \%)$, against stem rust $-106.0 \mathrm{~g} / \mathrm{m}^{2}$ $(13.5 \%)$, against yellow leaf spot $-132.0 \mathrm{~g} / \mathrm{m}^{2}(17.2 \%)$, against dwarf rust $-41.2 \mathrm{~g} / \mathrm{m}^{2}$ $(5.9 \%)$.

Comparison of biological and economic efficiency indicators in the experimental options and in the control with the biological standard Albit,RSS showed their comparability. The efficacy of the chemical standard Kolosal, KE was higher than in options using DL-59 and L-479.

\section{Conclusions}

The research revealed that L-479 preparation was the most effective on wheat against rust diseases and yellow leaf spot. Its biological efficacy ranged from $48.3 \%$ to $57.0 \%$ depending on the pathogen, and the increase in yield ranged from $3.7 \%$ to $22.1 \%$. DL-59 preparation showed the best biological efficacy against dwarf rust of barley $-89.8 \%$, the increase in yield was $3.5 \%$.

The induction of plant immunity by substances of both natural and abiogenic origin is a rather important and promising direction of biological plant protection. Therefore, the research to study the properties of the new inducers synthesized at the ARRIBPP, and showing their efficacy against cereal crop diseases, will be continued for their further effective implementation in plant protection systems.

The studies were carried out in accordance with the State Assignment No. 075-0037619-00 of the Ministry of Science and Higher Education of the Russian Federation as a part of the research on the topic 0686-2019-0008. 


\section{Acknowledgement}

We are really grateful to the Head of the Laboratory of immunity of grain crops to fungal diseases, Doctor in Biology G. V. Volkova for scientific management of research and Head of the Laboratory of plant growth regulators of the FSBSI ARRIBPP, PhD in Chemistry L.V. Dyadyuchenko for the preparations L-479 and DL-59 provided for the research.

\section{References}

1. A. Kokhmetova, O. Kremneva, G. Volkova, M. Atishova, Z. Sapakhova. J. Plant Pathol. 99(1):161-167 (2017) http://doi.org/10.4454/jpp.v99i1.3812

2. I.P. Matveeva, Yu.S. Kim, O.F. Vaganova, O.O. Miroshnichenko, O.Yu. Kremneva, G.V.Volkova, International Research Journal. 12-2(78), 40-44 (2018) https://doi.org/10.23670/IRJ.2018.78.12.044

3. J. Shah, R. Chaturvedi, Z. Chowdhury, B. Venables, R.A. Petros, Plant J. 79, 645658 (2014) http://doi.org/10.1111/tpj.12464

4. J. Shah, J. Zeier, Front. Plant Sci. 4(30) http://doi.org/10.3389/fpls.2013.00030

5. S. Mandal, Afr. J. Biotechnol. 9(47), 8038-8047 http://doi.org/10.5897/AJB10.984

6. G. Vandenborre, G. Smagghe, E.J.M. Van Damme, Phytochemistry 72, 1538-1550 (2011) http://doi.org/10.1016/j.phytochem.2011.02.024

7. J.A. O’Brien, A. Daudi, V.S. Butt, G.P. Bolwell, Planta 236, 765-779 (2012) http://doi.org/10.1007/s00425-012-1696-9

8. R. Davar, R. Darvishzadeh, A. Majd, Biol 68, 821-829 (2013) http://doi.org/10.2478/s11756-013-0235-X

9. P.U. Raoni, S. Pratyusha, Asia Pac. Entomol. 16, 131-136 (2013) http://doi.org/10.1016/j.aspen.2013.01.001

10. W.E.Durrant, X.Dong, Ann. Rev.Phytopathol. 42, 185-209 http://doi.org/10.1146/annurev.phyto.42.040803.140421

11. M. Thakur, B.S. Sohal, ISRN Biochem. 1-11 http://doi.org/10.1155/2013/762412

12. S. Farouk, M.A. Osman, Stress Physiol. Biochem. 7(3), 05-22 https://www.researchgate.net/publication/236894261_Farouk_S and_Osman_MA_2011_T he effect of plant defense elicitors on common bean Phaseolus vulgaris L growth an d yield in absence or presence of spider_mite Tetranychus urticae Koch infestation J ournal\#fullTextFileContent

13.J.H. Graham, M.E. Myers, Plant Dis. 95, 725-728 (2011) http://doi.org/10.1094/PDIS-09-10-0653

14. A. Garcia-Brugger, O. Lamotte, E. Vandelle, Mol. Plant Microbe Interact. 19(7), 711- 724 (2006) http://doi.org/10.1094/MPMI-19-0711

15. T.D. Bernonville, B. Marolleau, J. Staub, M. Gaucher, M-, N. Brisset J. Agric. Food Chem. 62, 11403-11411 (2014) http://doi.org/10.1021/jf504221x

16. L. Scalschi, G. Camañes, E. Llorens, E. Fernández-Crespo, M.M. López, P. García$\begin{array}{llllll}\text { Agustín, B. } & \text { B. Vicedo, } & \text { PloS } & \text { One } & \text { 9(9), } & \text { (2014) }\end{array}$ http://doi.org/10.1371/journal.pone.0106429

17. A. Singh, M. P. Pandey, A. K. Singh, R. E. Knox, K. Ammar, J. M. Clarke, F. R. Clarke, R. P. Singh, C. J. Pozniak, R. M. DePauw, B. D. McCallum, R. D. Cuthbert, H. S. Randhawa, and T. G. Fetch, Jr.Mol. breeding 31(2): 405-41 (2013) http://doi.org/10.1007/s11032-012-9798-4 
